\title{
Study on Interaction between Treasury Futures and Interest Rate Liberalization
}

\author{
M. Z. Zhou, J. Xiao \\ School of Economics and Management \\ Hubei University of Automotive Technology \\ Hubei, China
}

\begin{abstract}
As an emerging-market, China has a vast market while it is slow in developing financial derivatives. The Eighteenth Session of the Third Plenary makes it clear to improve the multilevel capital market system, accelerate to carry forward interest rate liberalization, and develop financial derivatives stably and orderly. The article focuses on the effects of the development of financial futures on carrying forward interest rate liberalization on the basis of analyzing the present status of Chinese financial futures market.
\end{abstract}

Keywords-financial derivatives; financial futures; treasury bond futures; interest rate liberalization

\section{INTRODUCTION}

The Eighteenth Session of the Third Plenary makes it clear to improve the multi-level capital market system, accelerate to carry forward interest rate liberalization, and develop financial derivatives stably and orderly. As one of the international financial markets mature financial products, treasury futures have very good results in terms of realized hedging. After interest rate liberalization, financial risk is more difficult to predict. Therefore, studying on interaction between treasury futures and interest rate liberalization is very important.

\section{CURRENT DEVElopment OF FinANCIAL FuturES MARKET IN CHINA}

At this stage, China's financial derivatives include futures markets and OTC financial derivatives. Futures markets are regulated by the China Securities Regulatory Commission, and composed by three commodity futures exchanges and a financial futures exchange. OTC financial derivatives including inter-bank OTC derivatives and bank counters OTC derivatives market, by People's Bank of China which is responsible for supervision. From a market share look, OTC market accounts for $80 \%$ of all derivatives markets, inside and outside the main difference lies in the system design, the extent of credit, market organizations, trade settlement and other aspects of government regulation. In recent years, with the development of information technology, the trend towards exchange-traded OTC transfer has become increasingly evident.[1]As standardized derivatives, financial futures has higher market transparency and lower transaction costs, which has been a necessity of healthy and stable development of financial.

April 16, 2010 CSI 300 Index Futures was traded officially, which opened the prelude to the development of China's financial futures markets. Since 4 years, the stock index futures market run smoothly together with stock market, it has played a positive role in the healthy development of China's capital market. The first, stock index futures play a "shock absorber" in the role of macro stability, to improve the stability of the stock market intrinsic effect is remarkable. IF compare before and after the listing, the CSI 300 Index fell 40 percent volatility. Stock market volatility extremes range reduced greatly, systemic risk decreased obviously, unilateral market features improved significantly. The second, the stock market risk of becoming "flood drainage" and investors hedge "escape pod", investors dare to shareholding. The third is to enhance the stock market has become the core competitiveness of the "booster", IF accelerate product and service innovation, attract and promote a variety of institutions and long-term funds into the market. Fourth ripening advanced investment concepts, individual investors become directly involved in indirect participation, become short-term speculative investment for the long term, become simply follow the trend of speculation for policy-driven trading. High turnover features in stock market improved significantly, speculative property investment weakened, property enhancements "chase sell" trading tends to decrease, systemic improvement in investor trading behavior.[2]

September 6, 2013 the five-year treasury bond futures was officially launched. Treasury futures is an important tool for investors to hedge, which is very important for accelerating the formation of a reasonable market benchmark interest rate. With the advance of interest rate liberalization, adjustment of social financing structure, as well as to accelerate the pace of financial innovation, financial institutions gradually increased sensitivity to changes in interest rates, competition has become even more intense. Treasury futures on the international financial market has been fully recognized and practiced. It can provide strong support in the management of interest rate risk, improvement asset management efficiency, and other aspects of the rich investment strategy for financial institutions. Treasury futures accelerate the pace of development of financial institutions. TF as the basis of interest rate risk management tools, since launched to maintain a good linkage with the spot market price, providing a guarantee for its hedging function. The correlation coefficient futures contracts and spot is $99 \%$, the average difference of closing base is 0.19 Yuan. Compared to the level of US \$ 0.12 in America, which is close to the international level in mature markets. Since its launch, TF yield to maturity on January 6, 2014 reached the highest point of $4.5293 \%$, corresponding spot price decline to $2.4 \%$, the market value of the loss of thousands of Yuan. It clearly showing that TF can better avoid the risk of bond trading. 


\section{THE STATUS QUO OF INTEREST RATE LIBERALIZATION IN CHINA}

Interest rate liberalization in China has experienced 30 years of complex and tortuous reform process, it is currently one of China's financial reform breakthrough point. Traced the course of the past, the central bank-led systematic interest rate reform began in the 1990s. Since the mid-1990s, Interest rate liberalization reform achieved successfully a breakthrough in four areas. ( I ) Release the inter-bank offered rate. LIBOR is often used as the benchmark interest rate, which reflects the supply and demand situation sensitive in money market. People's Bank of China released on the inter-bank offered rate control on June 1, 1996. The two sides decided to completely customize their lending interest rates based on supply and demand of funds. Since reform of interest rates liberalization has taken groundbreaking steps. ( II ) Achieve interest rate liberalization of inter-bank bond. Our exchange bond market achieved market-oriented interest rate of treasury bonds through a variety of ways, such as interest rate tender in 1996. People's Bank of China to establish the national inter-bank bond market in June 1997. Bonds held by deposit-taking financial institutions circulate into the unified inter-bank bond market, while achieving interest rate liberalization of treasury bonds trading. China Development Bank successfully issued policy bank financial bonds by interest rate tender in the interbank bond market in September 1998. Ministry of Finance restarted the bond issue in the inter-bank bond market by market-oriented approach in 1999. So far, China's inter-bank bond market fully realized the interest rate liberalization of treasury bonds and financial bonds. (III) Reduce the scope of deposit and lending rates. In accordance with the guidance of a gradual reform, People's Bank of China has liberalized the foreign currency in addition to individual term foreign currency rates, and gradually liberalized the RMB deposit interest rate floor and RMB loan ceiling. People's Bank of China has launched a pilot project to release RMB agreement deposit interest rate. Since 2000, People's Bank of China has implemented the reforms mentioned above to achieve financial interbank deposit interest rate liberalization. Practice has proved that independent pricing and pricing capability of financial institutions has been significantly improved. (IV) Foster money market benchmark interest rate. Benchmark interest rate market is the core of the formation mechanism. China's inter-bank market officially operated Shanghai Interbank Offered Rate in January 2007. Shanghai Interbank Offered Rate formed on the basis of Chinese inter-bank offered rate. Currently, Shanghai Interbank Offered Rate and money market development has formed a pattern of positive interaction, and has been widely used in the market price of the product. As can be seen from Table 1 and Table 2, the spread between money market rates and Shanghai Interbank Offered Rate maintain a lesser level. In addition to $3 \mathrm{M}$, the spread between Inter-bank market interest rates and Shanghai Interbank Offered Rate increased in chain. The spread between repo rate and Shanghai Interbank Offered Rate declined in chain except $1 \mathrm{M}$. Visible, financial markets pricing group is being formed based on the Shanghai Interbank Offered Rate, the interest rate parity relationship between the various increasingly clear and reasonable.[3]
TABLE I. THE DIFFERENCE BETWEEN INTER-BANK MARKET RATE AND SHIBOR IN 2014

\begin{tabular}{|c|c|c|c|c|c|c|}
\hline & IBO001 & IBO007 & IBO014 & IBO1M & IBO3M & IBO6M \\
\hline Sep. & 2.8 & 18.4 & 11.6 & 36.7 & 26.6 & 26.5 \\
\hline Aug & 2.7 & 15.7 & 5.9 & 26.3 & 39.6 & 25.0 \\
\hline $\begin{array}{l}\text { Jan- } \\
\text { Sep. }\end{array}$ & 3.6 & 14.9 & 14.6 & 34.4 & 49.1 & 36.8 \\
\hline
\end{tabular}

TABLE II. THE DIFFERENCE BETWEEN REPO MARKET INTEREST RATE AND SHIBOR IN 2014

\begin{tabular}{|c|c|c|c|c|c|c|}
\hline & R001 & R007 & R014 & R1M & R3M & R6M \\
\hline Sep. & 1.1 & 4.8 & 8.6 & 17.4 & 21.5 & 14.4 \\
\hline Aug & 1.3 & 5.3 & 12.7 & 11.3 & 22.7 & 24.2 \\
\hline $\begin{array}{l}\text { Jan- } \\
\text { Sep. }\end{array}$ & 2.5 & 4.5 & 8.2 & 11.4 & 50.0 & 51.3 \\
\hline
\end{tabular}

Progressive interest rate reform path leads to an unbalanced pattern of interest rates. The control of money market and bond market interest rate has basically liberalized. Degree of market interest rates has reached a high level. While the deposit interest rate control has not to achieve substantial breakthroughs yet. In this area there are still strict controls.

\section{FINANCIAL FUTURES FOR PROMOTING THE ROLE OF INTEREST RATE LIBERALIZATION}

Development of China's interest rate liberalization is always accompanied with financial markets. Figure 1 shows that economic growth in emerging markets rose significantly compared to developed countries. Speaking of the world economy in recent years, "The New York Times" commented that in the old developed countries, which is a steady economic growth, but the increase was not an era. While in the emerging world, the current economic growth in emerging economies is the fastest. China is the largest and most important emerging economies, the size of its economy is rapidly catching up to Europe, but also accompanied by the development of the financial problems of low efficiency of the system.[4] At present, with the development of China's underdeveloped financial markets, market players generally lack a reasonable use of financial instruments to hedge the risk, ability to resist financial risks is weak. This will directly affect our financial competitiveness in the international arena, as well as the right to speak at the International Monetary Funds. Therefore, in the process of China's interest rate liberalization we need one kind of financial instruments which can effectively avoid interest rate risk, stably operate the financial markets and promote the healthy and orderly development of the economy. In Western countries as the most mature of interest rate futures, bond futures does not require the introduction of a country has reached the full extent of the interest rate liberalization. As long as Treasury stock market to achieve the interest rate market, and has a certain size and liquidity, bond futures trading can be introduced. 1996 National Debt issuance formally introduced competitive bidding price, within one year of the implementation of debt issuance market interest rate tender, the interest rate market bond issuance has taken the first step in. 


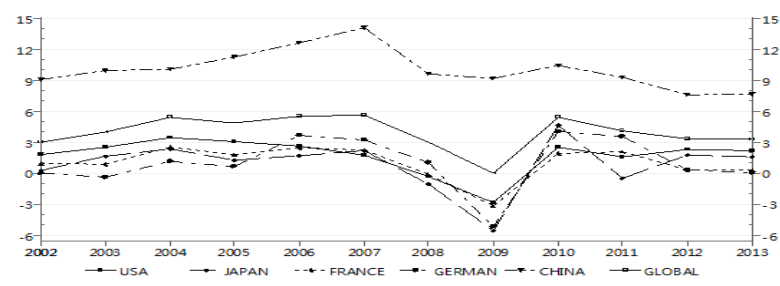

FIGURE I. WORLD ECONOMIC GROWTH RATE COMPARISON (GDP,\%)

September 6, 2013, five-year bond futures formally traded in China. More than a year ago, Treasury futures gradually appear in advancing the interest rate liberalization reform of the market functions.

\section{A. Treasury Bond Futures Help to Improve the Liquidity Level of Stock Market}

As a non-risk financial asset, debt is the foundation of a country's entire financial superstructure. Treasury market is the benchmark market, its status and function determines a healthy developed bond market should be with huge capital scale and highly mobility. Currently in our bond market, the severe shortage of liquidity in the secondary market is a fundamental problem. However, Treasury bond future has played a catalytic role in improving the liquidity of spot market.

\section{B. Bond Futures Will Help to Find the "Anchor" of Deposits and Loans Pricing}

The key of interest rate liberalization is looking for an "anchor" to be able to advance as a deposit pricing and loan pricing, which is the market recognized as the benchmark interest rate curve. Bond futures will help to find the "anchor" of deposits and loans pricing. Because the role of benchmark Treasury yield curve is irreplaceable. Given the bond futures market liquidity, transparency, and therefore it can yield longterm real interest rates reflect the trend. The term structure of interest rates based on the bond market will be the formation of all financial instruments to hedge accounting and operations. The reasonable term structure of interest rates will promote the effective implementation of all financial activities, while boosting the interest rate market-oriented reform process.[5]

\section{Treasury Bond Futures Become an Effective Tool to Hedge the Interest Rate Risk}

According to the China Financial Futures Exchange estimated that every one percentage point increase in interest rates, the bond market capitalization decreased by about 300 billion Yuan. With the deepening of the implementation of market-oriented interest rate reform, China's interest rate fluctuations will be larger and fluctuations in frequency will also accelerating. There is an urgent need for financial institutions to take advantage of bond futures hedging feature to avoid risks. Since the bond futures market operated, bond yields continued to rise, prices continued to fall. At present, for the larger brokers and investors to actively manage the interest rate risk of difficulty. Some financial institutions to participate in bond futures by making full use of hedging effectively reduce systemic risks of bond portfolio. Financial institutions to actively manage interest rate risk significantly improve the technological level.

\section{Treasury Futures Products in Favor of Innovative Financial Institutions}

Product innovation is the core of financial innovation. For financial institutions, especially commercial banks, the merits of products decide customers and the market, innovation ability determine the competitiveness of banks. From the experience of developed countries, the commercial bank which highly dependent on deposit and loan spreads, after the full realization of the interest rate market, the first thing is to face with deposit and loan spreads narrowed further, profit margins further compression of practical difficulties. It means more serious business risk and profitability challenges.[6] Commercial banks are required to change the profit model of financial innovation, while bond future is an irreplaceable role in promoting to innovative mechanisms of financial institutions. Under the premise of effective risk control, commercial banks and other financial institutions can develop more financial derivatives based on a combination of innovative bond, adding new profit growth point, to enhance the core competitiveness. Expected number of treasury futures as investment targets or fund products and information management products associated coming soon. Can be used for hedging or arbitrage bond ETF will expand the size and trading volume. It will create the conditions to launch many innovative products.

\section{CONCLUSION}

2007 US subprime crisis triggered a global financial turmoil, financial derivatives played a booster accelerator in the role of the financial crisis. Financial derivatives blamed by the parties, the domestic scholars have advocated the development of financial derivatives boycott. From our financial futures launched, is conducive to promote the interest rate liberalization. Therefore, we should recognize both the root causes of the US subprime crisis, but also an objective understanding of the importance of the development of financial derivatives to improve China's financial markets. For our country, developing and innovating financial derivatives in line with China's national condition, especially on risk aversion dominated.

\section{REFERENCES}

[1] China Financial Futures Exchange, Varieties statistics.

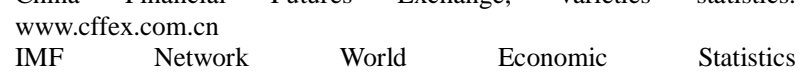

$\begin{array}{lllll}\text { [2] IMF } \quad \text { Network } & \text { World } & \text { Economic } & \text { Statistics } \\ \text { www.imf.org/external/index.htm } & & \end{array}$

[3] US Futures Industry Association network. Derivatives statistics www.futuresindustry.org/

[4] Hu Xinzhi \& Yuan Jiang, China's interest rate liberalization rational choice. International Economic Review, 6(2), pp. 132-145, 2011.

[5] Wu Fulin, What extent the interest rate liberalization in China. Economist, 4(4), pp. 70-76, 2012.

[6] Cheng Siwei, Issue of Chinese financial derivatives. Chinese Circulation Economy, 2(2), pp. 4-6, 2012. 